\title{
Potensi Wisata dalam Pembentukan City Branding Kota Pekanbaru
}

\author{
Dyas Larasati \\ Alumni Prodi Ilmu Komunikasi FPSB, Universitas Islam Indonesia \\ Muzayin Nazaruddin \\ Staff Pengajar Prodi Ilmu Komunikasi FPSB, Universitas Islam Indonesia
}

\begin{abstract}
ABSTRAK
Kota Pekanbaru merupakan Ibukota Provinsi Riau yang memiliki potensi di sektor pariwisata yang cukup besar. Penelitian ini dilakukan untuk mengkaji bagaimana potensi Kota Pekanbaru dilihat dari sektor wisata dalam mendukung pembentukan city branding? Upaya apa saja yang telah dilakukan pemerintah dalam mengoptimalkan potensi wisata tersebut, serta bagaimana strategi yang dapat dilakukan untuk mengoptimalkan potensi wisata tersebut dalam mendukung pembentukan city branding Kota Pekanbaru? Penelitin ini menggunakan pendekatan kualitatif. Data didapatkan melalui hasil wawancara, studi dokumentasi dan observasi. Penelitian ini menemukan bahwa strategi branding Kota Pekanbaru mengacu pada kerangka kerja branding kota oleh Kavartiz (2004). Strategi tersebut ialah mengkaji ulang mengenai visi dan strategi yang berhubungan dengan branding kota sebagai pintu gerbang budaya Melayu, dan melakukan sinergi antar stakeholders agar tercipta kerja sama yang baik. Selain itu, branding juga melibatkan warga lokal, pengusaha, dan pebisnis dalam mengembangkan dan mengantarkan brand. Selain itu, perlu pembentukan ruang publik yang mewakili branding Kota Pekanbaru sebagai pintu gerbang budaya Melayu seperti pembentukan taman terbuka untuk aktivitas kebudayaan.
\end{abstract}

Kata Kunci: city branding, potensi kota, Pekanbaru.

\begin{abstract}
Pekanbaru is capital of Riau which potential in tourism. This study was conducted to examine three main questions; how does tourism sector support the city branding of Pakanbaru? What are the government's efforts to optimize the tourism? How the strategies implemented in tourism support to Pekanbaru city branding? This research was conducted using a qualitative approach. Data were obtained through interviews, documentation, and observation studies. The study found that Pekanbaru City branding strategy refers to branding framework stated by Kavartiz (2004). The strategies were done by reviewing the vision and tactics related to branding the city as the 'gateway to the Malay culture'. Another step of branding strategy was making collaboration among stakeholders in order to create good cooperation. The activities of city branding involve local residents, entrepreneurs and business people in developing and delivering brand. In future, we suggest providing public space that represents the brand of Pekanbaru as a gateway to the Malay culture by the establishment of the open park for cultural activities.
\end{abstract}

Keyword: city branding, City's Potencial, Pekanbaru 


\section{PENDAHULUAN}

Sebuah kota baiknya mempunyai sebuah city branding atau yang dikenal dengan pembentukan identitas kota. Pembentukan identitas tersebut berguna agar sebuah kota dikenal oleh masayarakat baik lokal maupun global sehingga diharapkan pertumbuhan ekonomi dan kesejahteraan masyarakatnya semakin meningkat. Dalam menghadapi era globalisasi, sebuah kota harus mampu memanfaatkan keunggulan kotanya dalam segala bidang. Keunggulan tersebut didapat dari potensi kota berupa kekayaan alam, suku, pariwisata, infranstruktur kota hingga beraneka ragam kuliner khasnya. Setiap kota yang ada di dunia seharusnya mampu untuk menunjukkan karakteristik unik yang dimilikinya melalui potensi-potensi tersebut, setiap kota juga harus mempunyai tujuan ekonomi, budaya, dan politik yang jelas untuk membedakan sebuah kota dari kota lain sehingga mereka mampu berkompetisi dengan baik untuk menarik sumberdaya, wisatawan, dan penduduk secara global.

City branding merupakan suatu bentuk upaya untuk membentuk citra dan makna dalam benak target pasar mengenai sebuah kota. Melalui citra yang ingin dibentuk tersebut, sebuah kota dapat menarik calon investor dan turis untuk datang berkunjung. Untuk lebih menarik turis dan mempublikasikan branding yang tengah dibentuk, stakeholders dapat memanfaatkan media promosi seperti membuat sebuah slogan atau ikon yang mewakili dan menggambarkan brand kota sehingga upaya strategibranding tersebutmembuat suatu kota mampu "berbicara" dengan stakeholder, khususnya warga kota.

Kota Pekanbaru mempunyai banyak potensi yang bisa dikembangkan, terutama pada sektor pariwisata. Potensi wisata terdapat di Kota Pekanbaru, tapi sayangnya beberapa tempat wisata kurang dipublikasikan dengan baik. Kota Pekanbaru mempunyai sektor unggulan yang dapat dilihat dari banyaknya makanan khas dan budaya Melayu yang sangat kental di Kota Pekanbaru. Padahal, jika dikelola dengan baik maka akan banyak menarik wisatawan untuk berkunjung.

Potensi wisata di Kota Pekanbaru tidak lepas dari adanya etnis Melayu yang mendominasi di kota ini. Jika dikelola dan dibuat perencanaan pembangunan yang kuat, paduan etnis Melayu dan potensi wisata Pekanbaru dapat menjadi acuan branding kota. Dengan beberapa alasan tersebut, peneliti tertarik untuk menggali lebih dalam terhadap potensi wisata yang dimiliki pada kota ini. Kota Pekanbaru yang saat ini berstatus sebagai kota BERTUAH (Bersih, Tertib, Usaha Bersama, Aman, Harmonis) belum memiliki brand yang ingin diusung untuk dapat memunculkan ciri khas dan keunikan yang dimilikinya. Pekanbaru 
sendiri mempunyai slogan Kota BERTUAH yang sejak awal pembuatannya hingga saat ini belum pernah diperbaharui. Slogan Kota BERTUAH dirasa belum menghadirkan dan mewakili kota Pekanbaru di dalamnya. Untuk itu, pemahaman mengenai bagaimana konsep city branding diaplikasikan di Kota Pekanbaru dirasa sangat menarik untuk diteliti mengingat city branding Pekanbaru dapat bermanfaat bukan hanya untuk pemerintah Kota Pekanbaru, tetapi juga untuk perkembangan Kota Pekanbaru dan kesejahteraan warganya.

Potensi wisata Kota Pekanbaru tampaknya dapat dijadikan acuan untuk membentuk sebuah city branding. Potensi wisata dapat dikembangkan semenarik mungkin sehingga nantinya dapat mewakili branding yang ingin dibentuk oleh kota itu sendiri. Kota Pekanbaru dapat memanfaatkan budaya Melayu yang menjadi mayoritas penduduk di Pekanbaru. Bukti kentalnya budaya Melayu di Kota Pekanbaru dapat dilihat melalui infranstruktur kota yang dilengkapi dengan ukiran khas Melayu, atap selembayung, bahasa Melayu yang sering ditemukan di papan-papan peringatan di tengah kota dan bahasa Melayu yang dijadikan salah satu mata pelajaran sekolah-sekolah di Pekanbaru. Adapun kekayaan alam dan suburnya tanaman dijadikan modal untuk perkembangan wisata kuliner seperti buah durian yang diolah beragam jenis masakan, ikan patin, ikan selais dan masih banyak wisata kuliner khas Pekanbaru yang tidak lepas dari ciri khas budaya melayu itu sendiri. Beberapa potensi wisata tersebut berkaitan dengan sejarah Kota Pekanbaru sehingga peneliti merasa bahwa potensi ini sangat menarik untuk diteliti lebih dalam agar Kota Pekanbaru mempunyai sebuah ciri khas yang dapat dijadikan identitasnya.

Dengan memanfaatkan potensi wisata Kota Pekanbaru, pemerintah juga dapat memanfaatkan laju pertumbuhan ekonomi serta letak Kota Pekanbaru yang berada pada jalur perdagangan Internasional Selat Malaka, dan dekat dengan dua negara tetangga Malaysia dan Singapura. Lokasinya yang strategis mampu menarik negara tetangga untuk merkunjung dan membelanjakan uangnya di Kota Pekanbaru, baik untuk investasi maupun hanya sekedar untuk berwisata. Apabila potensi tersebut tidak dimanfaatkan dengan baik, Kota Pekanbaru dapat disaingi oleh negara tetangga.

Berdasarkan penjelasan singkat dari latar belakang diatas maka rumusan masalah dalam penelitian ini adalah bagaimana potensi sektor wisata Kota Pekanbaru dalam mendukung pembentukan city branding? Kemudian, bagaimana strategi yang dapat dilakukan untuk mengoptimalkan potensi wisata tersebut dalam mendukung pembentukan city branding? 


\section{LANDASAN TEORI}

City branding merupakan upaya pengembangan kota dari para perencana dan perancang kota beserta semua stakeholders (pemangku kepentingan). Seperti produk, jasa dan organisasi, kota sangat membutuhkan citra yang kuat dan berbeda dengan citra kota lainnya demi mengatasi persaingan untuk memperebutkan sumber daya ekonomi di tingkat lokal, regional, nasional maupun global. Melalui branding, sebuah kota mampu membangun ruh kota yang dapat ditunjukkan melalui infrastruktur kota untuk menarik wisatawan. Menurut Roll Martin (2006), sebuah kota perlu membentuk identitas yang berbeda di benak calon turis, pebisnis, pedagang, importer, dan konsumen. Roll Martin mendefinisikan branding kota sebagai berikut.

\begin{abstract}
Branding kota merupakan jawaban karena brand adalah jalan pintas mental yang memudahkan pengambilan keputusan yang perlu dilakukan.Branding juga dapat memenuhi sasaran di pasar dunia melalui menarik investasi dan pekerja yang memiliki keterampilan tinggi (skilled worker) ${ }^{1}$
\end{abstract}

Banyak definisi mengenai branding kota yang dapat dijadikan acuan untuk membentuk sebuah brand. Beberapa definisi city branding merujuk pada pembangunan kota yang diikuti dengan

${ }^{1}$ Boy Syahbana, et.al.,Branding Tempat: Membangun Kota, Kabupaten, dan Provinsi Berbasis Identitas,(Jakarta Selatan: Makna Informasi, 2014), hlm. 56. membangun ruh atau ciri khas sebuah kota. Adapun defenisi lain mengenai city branding dikemukakan oleh Kavartzis (Ina Primasari, 2014) sebagai berikut.

City branding dipahami sebagai sarana untuk mencapai keunggulan kompetitif dalam rangka untuk meningkatkan investasi dari pariwisata, dan juga sebagai pencapaian pembangunan masyarakat.Memperkuat identitas lokal dan identitas warga dengan kota mereka dan mengaktifkan semua kalangan sosial demi menghindari pengucilan dan kerusuhan sosial ${ }^{2}$

Selain meningkatkan kualitas pariwisata untuk meningkatkan investasi di sektor tersebut, pemasaran tempat diperlukan untuk membuat sebuah identitas kota yang nantinya akan memuaskan kebutuhan target pasar. Seperti diungkapkan oleh Kotler (Syahbana, 2014), "Pemasaran tempat adalah perancangan suatu tempat untuk memuaskan kebutuhan target pasar. Keberhasilan terjadi ketika warga kota dan pelaku usaha sangat senang dengan komunitasnya, dan para pendatang dan investor mendapatkan keinginannya ${ }^{3}$."

Konsep pemasaran kota ini berkembang menjadi pembentukan citra atau city branding melalui pengembangan ekonomi dan meningkatkan kualitas hubungan antara warga dengan kota. City

\footnotetext{
${ }^{2}$ Ina Primasari, et.al.,City Branding Solo Sebagai Kota Wisata Budaya Jawa (Studi Deskriptif Kualitatif tentang City branding Solo sebagai kota wisata budaya Jawa oleh Dinas Kebudayaan dan Pariwisata kota Solo), Skripsi Sarjana pada FISIP Universitas Sebelas Maret Surakarta: tidak diterbitkan.

${ }^{3}$ Ibid, hlm. 16.
} 
branding berkembang pada sebuah kota yang sedang membangun sebuah identitas kota. Identitas ini tentunya akan mencerminkan potensi kota dan upaya yang sedang dibentuk dalam pembangunan citra kota tersebut. Setelah identitas tersebut terbentuk, harus ada komunikasi brand yang yang dilakukan secara efektif untuk mempromosikan city branding secara lokal maupun global.
Pemasaran kota memiliki beberapa tingkatan strategi, seperti perencanaan (planning), pemasaran (marketing) dan target pasar (target markets). Perencanaan merupakan inti dari pemasaran tempat dan melibatkan pemangku kepentingan kota, yaitu warga kota, pemerintah kota dan komunitas dunia usaha.

Kavartzis lebih lanjut mengintegrasikan kerangka kerja brand kota dengan mengelompokkan komponen yang membantu membangun brand kota4.

\begin{tabular}{|l|l|}
\hline Visi dan Strategi & $\begin{array}{l}\text { Visi yang dipilih untuk masa depan kota dan } \\
\text { pengembangan stratgi yang jelas untuk } \\
\text { merealisasikan visi tersebut }\end{array}$ \\
\hline Sinergi & $\begin{array}{l}\text { Kesepakan dan dukungan dari seluruh } \\
\text { pemangku kepentingan yang relevan dan } \\
\text { adanya partisipasi yang berimbang }\end{array}$ \\
\hline Komunitas Lokal & $\begin{array}{l}\text { Penentun prioritas pada kebutuhan lokal } \\
\text { yang melibatkan warga lokal, pengusaha dan } \\
\text { pebisnis dalam mengembangkan dan } \\
\text { mengantarkan brand }\end{array}$ \\
\hline Infrastruktur & $\begin{array}{l}\text { Penyediaan kebutuhan dasar yang harus } \\
\text { diberikan kota untuk memnuhi harapan } \\
\text { yang dibangun melalui brand }\end{array}$ \\
\hline Getaways) Kota dan Gerbang (Cityscape and & $\begin{array}{l}\text { Kemampuan lingkungan buatan untuk } \\
\text { mempresentasikan diri dan memperkuat } \\
\text { atau merusak brand }\end{array}$ \\
\hline Budaya Internal & $\begin{array}{l}\text { Penyebaran orientasi brand melalui } \\
\text { pengelolaan dan pemasaran perkotaan itu } \\
\text { sendiri }\end{array}$ \\
\hline Kesempatan & $\begin{array}{l}\text { Kesempatan yang terbuka untuk individu } \\
\text { tertentu seperti gaya hidup urban, jasa, } \\
\text { pendidikan, dan lainnya serta perusahaan } \\
\text { (keuangan,SDM) yang menonjolkan potensi } \\
\text { tempat }\end{array}$ \\
\hline Komunikasi & $\begin{array}{l}\text { Upaya menyelaraskan semua pesan } \\
\text { komunikasi yang bersifat intensional }\end{array}$ \\
\hline
\end{tabular}

Tabel I.1 Kerangka Kerja Brand Kota

Sumber: Branding Tempat: Membangun Kota, Kabupaten, dan Provinsi Berbasis Identitas

${ }^{4}$ Boy Syahbana, et.al., Branding Tempat: Membangun Kota, Kabupaten, dan Provinsi Berbasis Identitas,(Jakarta Selatan: Makna Informasi, 2014), hlm. 78. 


\section{METODE PENELITIAN}

Paradigma yang penulis gunakan dalam penelitian ini adalah paradigma kontruktivisme. Paradigma ini memandang ilmu sebagai analisis sistematis terhadap socially meaningful action melalui pengamatan langsung dan terperinci terhadap pelaku sosial yang bersangkutan menciptakan dan memelihara atau mengelola dunia sosial mereka.5 Dengan begitu, peneliti dapat menjelaskan mengenai perilaku sosial yang terjadi di lingkungan peneliti.Serta mengambil makna yang tampak dari hasil pengamatan yang peneliti lakukan.

Pendekatan yang digunakan dalam penelitian adalah pendekatan kualitatif, dimana segi penyajiannya dari hasil temuan dipaparkan dalam bentuk deskriptif tanpa adanya prosedur statistik. Pendekatan kualitatif juga digunakan untuk mengungkap situasi sosial tertentu dengan mendeskripsikan kenyataan secara benar, dibentuk oleh kata-kata berdasarkan teknik pengumpulan data dan analisis data yang relevan yang diperoleh dari suatu kondisi yang alamiah $^{6}$. Pengambilan data penelitian ini melalui subyek dan obyek penelitian yang didapatkan melalui seseorang, lembaga, masyarakat dan lain-lain.

${ }^{5}$ Ibid, hlm.3.

${ }^{6}$ Djam'an Satori dan Aan Komariah, Metodologi Penelitian Kualitatif, (Bandung: Alfabeta, 2012), hlm.25.
Pemilihan narasumber menggunakan model snow ball sampling dimana narasumber diwawancarai dan selanjutnya peneliti meminta rekomendasi narasumber lain yang juga berkompetensi untuk menjawab beberapa pertanyaan yang diajukan oleh peneliti.

\section{ANALISIS DAN PEMBAHASAN}

1. Potensi Kota Pekanbaru Provinsi Riau terdiri dari 10 kabupaten dan 2 kota yang terdiri dari Kabupaten Bengkalis, Siak, Rokan Hilir, Rokan hulu, Kampar, Kuantan sengingi, Indragiri hulu, Indragiri hilir, Kepulauan Meranti, dan Pelelawan. Termasuk pula Kota Dumai yang dekat dengan Kota Pekanbaru dan tidak kalah dalam bidang perkebunan, tempat wisata dan industriindustri besar yang sering kedatangan turis dan calon investor dari luar Provinsi Riau.Hal tersebut ternyata memberikan dampak positif bagi Pekanbaru, karena setiap tamu yang datang harus melewati Kota Pekanbaru terlebih dahulu.Itulah salah satu keuntungan Kota Pekanbaru yang memiliki Bandar Udara Internasional Sultan Syarif Kasim II sebagai bandara satu-satunya di Provinsi Riau. Turis maupun calon investor yang singgah di Pekanbaru sebelum menuju kota tujuannya, dimanfaatkan Kota Pekanbaru untuk menjual potensi wisata yang dimilikinya.

Batas Kota Pekanbaru sebelah Utara adalah Kabupaten Siak dan 
Kabupaten Kampar. Bagian Selatan berbatasan dengan Kabupaten Kampar dan Kabupaten Pelelawan.Sebelah Barat berbatasan dengan Kabupaten Kampar, kemudian sebelah Timur berbatasan dengan Kabupaten Siak dan Kabupaten Pelelawan.Baru bekerjasama dengan kabupaten terdekat yaitu Siak, Kampar dan Pelelawan bukan berarti kabupaten lain tidak memiliki potensi besar untuk diajak bekerjasama. Kota Pekanbaru dekat dengan kabupaten yang dapat dijangkau dengan mudah melalui transportasi laut, darat dan udara. Selain itu, Kota Pekanbaru diuntungkan dengan statusnya yang merupakan Ibukota Provinsi Riau dan Bandara Intersnasional Sultan Syarif Kasim II yang berada di Kota Pekanbaru.

Dinas Kebudayaan dan Pariwisata menyadari bahwa Kota Pekanbaru kekurangan tempat wisata yang dapat menarik pengunjung untuk datang ke Kota Pekanbaru, apalagi jika dibandingkan dengan kota dan kabupaten di sekitarnya. Namun, kekurangan tersebut harusnya dapat ditutupi dengan kekayaan kuliner, pariwisata dan budaya Melayu yang sangat kental di Pekanbaru.
Potensi kota adalah salah satu faktor penting yang harus dioptimalisasikan demi perkembangan perekonomian kota. Potensi tersebut berupa lokasi wisata yang dimiliki Kota Pekanbaru. Sektor pariwisata mempunyai banyak jenisnya, seperti wisata budaya, wisata bahari, wisata alam, wisata kuliner, wisata konvensi, wisata sejarah dan wisata ziarah. Banyak jenis wisata yang dapat dinikmati dan menjadi penarik wisatawan untuk datang berkunjung. Namun, setelah melakukan observasi, peneliti menemukan beberapa lokasi wisata yang ada di Kota Pekanbaru. Kemudian, lokasi wisata tersebut peneliti kelompokkan sesuai jenis-jenis pariwisata. Kota Pekanbaru memang tidak memiliki seluruh jenis-jenis pariwisata tetapi saat ini di Pekanbaru terdapat beberapa jenis wisata yaitu, wisata alam, wisata sejarah, wisata seni budaya dan wisata kuliner.Pariwisata tersebut menjadi sarana penting yang dapat menunjang branding kota. Berikut lokasi wisata di Kota Pekanbaru yang dapat dikembangkan untuk menarik wisatawan 


\begin{tabular}{|l|l|l|}
\hline No. & \multicolumn{1}{|c|}{ Aspek } & \multicolumn{1}{|c|}{ Potensi } \\
\hline 1. & Seni Budaya & a. Tari Persembahan \\
& & b. Bangunan Arsitektur Melayu \\
& & c. Acara Kebudayaan Tahunan \\
\hline 2. & Kuliner & a. Asam Pedas Baung \\
& & b. Pasar Wisata Pasar Bawah \\
& & c. Pancake Durian \\
\hline 3. & Wisata Alam & d. Bolu Kembojo \\
\hline 4. & Wisata Sejarah & a. Alam Mayang \\
& & b. Water Front City (WFC) \\
& & a. Museum Sang Nila Utama \\
& & c. Mesjid Agung Kota Pekanbaru \\
\hline
\end{tabular}

Perkembangan Kerajaan Siak sangat luas dan hingga saat ini dapat dirasakan ketika berkunjung ke Kota Pekanbaru. Masyarakat dapat melihat arsitektur bangunan yang memiliki Selembayung. Kemudian, terdapat tarian khas sambutan budaya Melayu, yaitu tari persembahan yang dibentuk pada saat pembukaan kongres pemuda dan diberi nama Tari Makan Sirih. Kota Pekanbaru mempunyai beberapa potensi pada gedung berarsitektur yang kental dengan budayaMelayu Riau yang bernama Komplek Bandar Seni Raja Ali Haji (Bandar Serai).Di dalam komplek tersebut terdapat pula rumah-rumah panggung khas Melayu berukuran kecil.Kawasan Komplek Bandar Seni Raja Ali Haji atau yang dikenal juga dengan Lapangan Purna MTQ terdapat Anjungan Seni Idrus Tintin dan bangunan Taman Budaya Riau. Pusat Informasi Budaya Melayu terdapat pula di dalam Anjungan Seni Idrus Tintin ini, selain bangunannya yang kental dengan budaya Melayu, bangunan ini juga menjadi ikon Kota Pekanbaru. Selain itu, terdapat tradisi budaya Melayu yang masih sering dilaksanakan yaitu Petang Megang dan Festival Lampu Colok.

Kota Pekanbaru memiliki makanan khas yang sulit ditemukan di luar Kota Pekanbaru. Kuliner khas Pekanbaru dapat ditemui di beberapa rumah makan seperti RM. Pondok Patin HM. Yunus dan Pondok Asam Pedas Baung khusus menjual masakan khas Melayu. Satu lagi wisata kuliner yang wajib didatangi oleh wisatawan bila ke Pekanbaru adalah Pasar Bawah yang dikenal sebagai pusat wisata belanja, salah 
satunya seperti lempuk durian dan ikan selais. Kerajinan khas Pekanbaru hingga makanan impor dari Malaysia atau pun Singapura terdapat pula di Pasar Bawah tersebut.

Alam Mayang adalah tempat wisata yang ada di Kota Pekanbaru dan menjadi tempat bermain sambil beristirahat oleh warga Pekanbaru. Suasana tempat wisata ini dipenuhi oleh pohon-pohon rindang dan wahana bermain. Alam mayang mengusung konsep rekreasi di alam terbuka. Beragam jenis kendaraan air yang disediakan di Alam mayang diantaranya kapal penumpang, perahu dan sepeda air. Kota Pekanbaru punya jembatan Leighton yang menyambungkan jalan diatas sungai Siak. Sungai Siak yang membelah Riau ini dapat dimanfaatkan untuk dijadikan wisata air. Meskipun masih dalam tahap proses, pembuatan wisata air ini telah dimulai dengan adanya Bus Air (BA) Senapelan. Tepat dipinggir sungai Siak ini terdapat taman untuk bersantai sambil melihat nelayan dan kapal yang melewati sungai Siak. Taman ini dinamakan Water Front City (WFC).

Peninggalan bersejarah Kota Pekanbaru dapat ditemui di Museum Sang Nila Utama. Museum ini hingga tahun 2010 mempunyai 3.886 koleksi. Kota Pekanbaru memiliki Mesjid Agung AnNur dan Masjid Raya Senapelan yang sayangnya saat ini telah mengalami renovasi bangunan. Perpustakaan Wilayah Soeman HS daerah juga merupakan salah satu bangunan yang sangat berpotensi dan wajib dioptimalkan di Kota Pekanbaru. Perpusatakaan ini dibangun dengan bentuk sebuah buku yang sedang terbuka jika dilihat dari atas.P emerintah Kota khususnya Dinas Budaya dan Pariwisata Kota Pekanbaru tidak tinggal diam dalam memanfaatkan potensi wisata yang ada di Pekanbaru.Hanya saya perlu optimalisasi dalam mengolah potensi yang sudah ada tersebut. Adapun langkah pemerintah yaitu mengadakan pemilihan bujang dan dara, festival bandar senapelan Kota Pekanbaru, menjadikan Kota Pekanbaru sebagai kota metropolitan yang madani, membuat fasilitas taman publik dikawasan Sungai Siak dan renovasi masjid agung dan masjid raya.

\section{Pembentukan City Branding}

Pada uraian berikut, peneliti akan menjabarkan tahapan kinerja branding kota yang dituliskan berdasarkan strategi city branding menurut Kavartiz', yaitu pembuatan visi dan strategi, melakukan sinergi, melibatkan komunitas lokal, infranstruktur, pembuatan ruang kota dan gerbang, budaya internal, memanfaatkan kesempatan yang ada dan komunikasi. Acuan tersebut penulis jabarkan kembali dibawah ini:

a. Visi dan Strategi. Kota Pekanbaru yang kental dengan kebudayaan Melayu ini sebelumnya telah membuat visi, yaitu "terwujudnya

${ }^{7}$ Ibid, hlm.78. 
Kota Pekanbaru sebagai pusat perdagangan dan jasa, pendidikan serta pusat kebudayaan Melayu, menuju masyarakat sejahtera berlandaskan iman dan taqwa”. Untuk mencapai visi tersebut, Kota Pekanbaru juga telah membuat misi yang terdiri dari 6 poin utama, yakni sebagai berikut.

1) Meningkatkan kualitas Sumber Daya Manusia (SDM) yang memiliki kompetensi tinggi, bermoral, beriman dan bertaqwa serta mampu bersaing di tingkat lokal, nasional maupun internasional.

2) Meningkatkan kualitas Sumber Daya Manusia (SDM) melalui peningkatan kemampuan/ keterampilan tenaga kerja, pembangunan kesehatan, kependudukan dan keluarga sejahtera.

3) Mewujudkan masyarakat berbudaya Melayu, bermartabat dan bermarwah yang menjalankan kehidupan beragama, memiliki iman dan taqwa, berkeadilan tanpa membedakan satu dengan yang lainnya serta hidup dalam rukun dan damai.

4) Meningkatkan infrastruktur daerah baik prasarana jalan, air bersih, enegeri listrik, penanganan limbah yang sesuai dengan kebutuhan daerah terutama infrastruktur pada kawasan industri, pariwisata serta daerah pinggiran kota.

5) Mewujudkan penataan ruang dan pemanfaatan lahan yang efektif dan pelestarian lingkungan hidup dalam mewujudkan pembangunan yang berkelanjutan.

6) Meningkatkan perekonomian daerah dan masyarakat dengan meningkatkan investasi bidang industri, perdagangan, jasa dan pemberdayaan ekonomi kerakyatan dengan dukungan fasilitas yang memadai dan iklim usaha yang kondusif.

Pencapaian visi Kota Pekanbaru sebaiknya menjadikan pengembangan kebudayaan Melayu sebagai fokus pemerintahan agar terjadi perkembangan yang signifikan sehingga pencerminan kebudayaan Melayu dapat menjadi identitas kota Pekanbaru. Sementara itu, misi Kota Pekanbaru tersebut sudah baik penetapannya, tetapi dalam peningkatan Sumber Daya Manusia (SDM) dan peningkatan infrastruktur, sebaiknya ditambahkan dengan syarat tidak meninggalkan budaya Melayu seperti yang sudah dituliskan pada poin ketiga. Apabila peningkatan SDM dan peningkatan infranstuktur tidak memikirkan sejarah Melayu, maka Kota Pekanbaru akan kehilangan identitasnya sebagai kota berbudaya Melayu. Seperti yang terjadi pada renovasi Masjid Raya Kota Pekanbaru yang akhirnya kehilangan bentuk aslinya.

Pembangunan infrastruktur dan peningkatan SDM yang didukung seperti menggunakan baju Melayu pada hari khusus, serta peningkatan infrastruktur 
bangunan berarsitektur Melayu akan mendorong Kota Pekanbaru untuk menjadi pintu gerbang budaya Melayu. Kemudian misi pada poin kedua sepertinya sudah diwakili oleh poin pertama, yaitu sama-sama meningkatkan SDM yang memiliki kompetensi tinggi yang mampu bersaing ditingkat lokal, nasional maupun internasional.

Melihat poin keempat, kelima dan keenam, memiliki kesamaan, yaitu meningkatkan infrastruktur berupa ruang publik serta mengelola pemukiman yang masih digunakan sekitar 25\%, sisanya belum belum dikelola dengan baik dan disisakan untuk ruang hijau. Dengan peningkatan infrastruktur tersebut, tentunya poin keenam akan terlaksana, yaitu meningkatnya perekonomian daerah dan masyarakat serta menarik calon investor untuk berinvestasi di Kota Pekanbaru. Untuk mempersingkat misi tersebut apabila disesuaikan dengan usulan peneliti maka Kota Pekanbaru membuat misi peningkatan infrastruktur dan tidak lupa untuk memanfaatkan potensi kota serta menjaga dan mengelola dengan baik lokasi wisata yang telah ada. Pengembangan infrastruktur tersebut bertujuan agar brand Kota Pekanbaru sebagai pintu gerbang kebudayaan Melayu dapat terwujud.

Kemudian, misi Kota Pekanbaru berfokus dalam memberikan perhatian khusus bagi pengembangan infrastruktur dengan memberikan anggaran yang dibutuhkan, serta meningkatkan kerjasama dengan calon investor untuk pengembangan pariwisata. Seluruh stakeholder turut serta dalam urusan pariwisata di Kota Pekanbaru yang tanggung jawabnya dipegang oleh Dinas Kebudayaan dan Pariwisata.Masingmasing stakeholder harus lebih meningkatkan kinerja dalam pengembangan Kota Pekanbaru kearah yang lebih baik.

b. Sinergi, yakni pemerintah Kota Pekanbaru tidak bisa bekerja sendiri dalam mewujudkan visi yang telah dibuat, tetapi perlu adanya komunikasi antar stakeholder seperti melakukan diskusi mengenai perencanaan, pemasaran dan target pasar terhadap strategi untuk mengoptimalkan potensi dan melakukan promosi kotaPekanbaru secara efektif ${ }^{8}$.

Organisasi pelaksana branding kota dapat menjadi bagian dari pemerintah daerah yang ditempatkan di Badan Perencanaan Daerah yang menggabungkan fungsi perencanaan (BAPPEDA), pelaksanaan (Dinas Pekerjaan Umum), pemasaran (Badan Penanaman Modal Daerah) dan komunikasi (Humas). Fungsi-fungsi tersebut tidak boleh tumpang tindih dengan fungsi-fungsi mereka seharusnya.Organisasi tersebut melakukan kerja mereka sendirisendiri agar tujuan dapat dicapai melalui strategi yang telah dibuat. Catatan terpenting adalah organisasi seharusnya berisikan semua kelompok-kelompok perencana

\footnotetext{
${ }^{8}$ Boy Syahbana, Boy Syahbana, et.al., Branding

Tempat: Membangun Kota, Kabupaten, dan

Provinsi Berbasis Identitas, (Jakarta Selatan: Makna Informasi, 2014), hlm. 17.
} 
(pemda, warga dan dunia usaha) dan bertanggung jawab langsung kepada kepala daerah serta berkolaborasi dengan dinas terkait9.

Kerja sama dengan Badan Perencanaan Pembangunan Daerah untuk melakukan koordinasi dalam merumuskan strategi perencanaan dan membangun infrastruktur kota serta wewenang Dinas Kebudayaan dan Pariwisata yang melakukan pembenahan dan penataan tempat wisata seni budaya, kuliner, alam, dan sejarah agar dapat dikelola dan dioptimalkan dengan baik. Kemudian, melakukan sosialisasi kepada masyarakat dan pelaku seni dan budaya serta melaksanakan event-event seni dan budaya melayu mengikuti pameran pariwisata baik didalam maupun diluar negeri bekerjasama dengan Lembaga Adat Melayu (LAM). Kerjasama dengan Dinas Pendidikan juga diperlukan untuk menanamkan nilai budaya Melayu ke sekolah-sekolah, seperti mengusulkan pelajaran mengenai tulisan Melayu hingga adat istiadat Melayu.

Kerja sama dengan Dinas Perhubungan Komunikasi dan Informatika serta Badan Penanaman Modal Daerah untuk mengkomunikasikan dan membantu promosi lokasi wisata serta brand Kota Pekanbaru sebagai pintu gerbang budaya Melayu agar disosialisasikan dengan efektif kepada publik. Kerja sama dengan pelaku seni juga turut dijaga, karena tanpa pelaku seni

${ }^{9}$ Ibid, hlm. 232 makan budaya Melayu Kota Pekanbaru akan luntur perlahan seiring masuknya budaya asing. Serta tidak lupa pula bekerjasama dengan seluruh masyarakat Kota untuk selalu menjaga wisata yang ada di Kota Pekanbaru. Dengan terciptanya kerjasama yang baik, maka masing-masing pihak akan fokus melaksanakan tugasnya untuk mencapai branding Kota Pekanbaru. Dengan begitu diharapkan seluruh stakeholder akan menjaga potensi kota agar branding yang ingin dicapai akan dikenal oleh publik.

c. Komunitas Lokal, yakni penentuan prioritas pada kebutuhan lokal yang melibatkan warga lokal, pengusaha, dan pebisnis dalam mengembangkan dan mengantarkan brand. Untuk membentuk sebuah branding kota sebagai pintu gerbang kebudayaan, Kota Pekanbaru tentu memanfaatkan Bandara Internasional Sultan Syarif Kasim II sebagai fasilitas kedatangan wisatawan yang akan berkunjung ke Pekanbaru dan kabupaten sekitarnya. Sebagai rumah utama untuk menyambut kedatangan, Kota Pekanbaru perlu mengembangkan infrastruktur kota. Bangunan berarsitektur Melayu perlu dikelola dengan baik, tempat wisata dan kuliner dikelola secara menarik. Dalam pembangunan tersebut, Pemerintah kota baiknya bekerjasama dengan pengusaha dan pebisnis. Seperti adanya kerjasama dengan 
Asosiasi Pengusaha Jasa Boga Indonesia (APJI) yang mengelola pengusaha di Kota Pekanbaru. Khususnya, mengelola pengusaha kuliner dan oleh-oleh khas Kota Pekanbaru.

Pelibatan tersebut dapat dilakukan dengan melakukan pelatihan serta mengajarkan pengembangan usaha untuk berinovasi agar pengusaha Kota Pekanbaru mengolah potensi kuliner dan budaya dengan baik. Dengan adanya kerjasama tersebut, perekonomian Kota Pekanbaru juga akan meningkat. Potensi Kota Pekanbaru dapat pula diolah dengan bekerjasama dengan pengusaha lokal yang didukung dengan pembuatan lokasi khusus. Sebagai contoh kerja sama lainnya yaitu yang ada di Kota Bali dimana tourist information center sangat mudah kita temui di pinggi jalanan Bali apabila kita datang berkunjung. Booth tourist information center tersebut tidak lepas daripebisnis pariwisata lokal Bali yang dapat mengambil peluang pariwisata di daerahnya.

d. Infrastruktur, yakni penyediaan kebutuhan dasar yang harus diberikan kota untuk memenuhi harapan yang dibangun melalui brand. Sebagai pintu utama menyambut kedatangan wisatawan, tentunya Kota Pekanbaru menjadi kota transit yang baiknya memanjakan mata wisatawan terhadap infrastruktur kota. Tidak banyak wisata alam yang dimiliki Kota Pekanbaru, untuk itu pengembangan taman publik, bangunan berarsitektur Melayu dan infrastruktur yang berkaitan dengan budaya Melayu perlu dikelola dengan baik. Kemudian Kota Pekanbaru perlu mereaslisasikan rencananya untuk melengkapi fasilitas Daerah Milik Jalan (DMJ) di Pasar Bawahagar kondisi pasar yang menjadi tujuan para wisatawan itu bisa lebih nyaman, teratur dan memberikan ruang bagi pejalan kaki. Selain itu pembuatan DMJ ini juga menguntungkan pemilik toko karena pengunjungnya akan bertambah banyak. Selain itu Kota Pekanbaru dapat mencontoh Kota Bali yang memiliki kawasan dengan fokus usaha berbeda-beda, seperti kampung rotan, kampung kayu, dan kampung kopi. Apabila mengunjungi Bali, beberapa tour guide mengajak wisatawan salah satunya mengunjungi kampung kopi khususnya pengembangan kopi luwak yang berada di daerah Bangli, Batur Tengah. Kota Pekanbaru sendiri bisa membuat kampung wisata kerajinan rotan yang beberapa pengrajinnya berada di Kecamatan Rumbai. 
e. Ruang Kota dan Gerbang (Cityscape and Getaways), yang mencakup kemampuan lingkungan buatan untuk mempresentasikan diri dan memperkuat atau merusak brand. Ini penting dilakukan karena tidaklah cukup mengandalkan wisata alam atau wisata budaya yang sudah ada. Pembentukan ruang publik yang mewakili branding Kota Pekanbaru juga perlu dibuat. Namun, jika ruang publik tersebut gagal dalam mempresentasikan diri maka dapat merusak brand yang ingin dibuat. Kota Pekanbaru dapat mencontoh Kota Bandung yang dikenal dengan kota kreatif, dimana branding kota kreatif tersebut diwakili dengan dibuatnya taman lansia dan taman jomblo yang sebelumnya belum pernah ada di kota-kota di Indonesia. Kemudian, sebagai contoh kota kreatif juga ingin diusung oleh Kota Turin (Torino), Italia yang dibarengi dengan memperbaharui bangunan yang dianggap menjadi ikon Kota Turin seperti bangunan Luci d'Artista (art lights), Lingotto (ex-Fiat Factoy) dan pemasangan promosi banner bertuliskan passion lives here di pinggir-pinggir jalan Kota Turin ${ }^{10}$. Kota Pekanbaru sendiri dapat

${ }^{10}$ Alberto Vanolo, The Image of The Creative City: Some Reflections on Urban Branding in Turin, Science Direct, diakses dari http://www.sciencedirect.com/science/article/pii/SO 264275108000772, pada tanggal 9 Juni 2015 pukul 21.08 membuat ruang kota seperti taman kebudayaan, seperti taman terbuka dimana pada hari tertentu taman terbuka tersebut mengadakan pagelaran seni yang dapat dilakukan oleh siapa saja yang memiliki karya seni. Dengan begitu, bakat yang dimiliki oleh masyarakat Kota Pekanbaru juga dapat disalurkan dengan baik. Namun apabila taman kebudayaan tersebut tidak dikelola dan dijaga dengan baik maka akan sia-sia dan merusak brand yang akan dibentuk.

f. Budaya Internal. Ini mencakup pengembangan Kota Pekanbaru baiknya selalu membawa sejarah yang melekat pada dirinya. Sejarah Kota Pekanbaru adalah berbudaya Melayu yang dibawa oleh Kerajaan Siak. Salah satu branding yang dapat dilakukan adalah dengan melestarikan pakaian Melayu yang digunakan pada hari khusus oleh karyawan maupun siswa. Apabila ada hari batik, maka diharapkan akan ada hari khusus berbusana Melayu.

g. Kesempatan. Pembuatan branding kota tidak hanya melibatkan Pemerintah Kota Pekanbaru saja, tetapi perlu melibatkan masyarakat Kota Pekanbaru khususnya anak muda yang saat ini memiliki gaya hidup urban. Contohnya anak muda di Kota Pekanbaru dapat memanfaatkan kemudahaan internet dan media sosial seperti twitter atau 
instagram yang tengah digandrungi saat ini. Anak muda bertugas mengenalkan kuliner Kota Pekanbaru dengan membuat sosial media khusus kuliner Pekanbaru atau sosial media mengenai informasi event kebudayaan yang akan dilaksanakan di Kota Pekanbaru.

Dengan memanfaatkan kreativitas anak muda, Pemerintah bisa membuat sebuah ajang perlombaan membuat logo atau tagline yang mewakili Kota Pekanbaru sebagai pintu gerbang budaya Melayu. Berbicara tentang anak muda, Kota Pekanbaru perlu mencontoh Kota Bandung yang memanfaatkan kekuatan anak muda yang produktif dan kreatif dalam membuat logo dan taman kreatif di Kota Bandung serta memberikan semangat dalam berkarya dan berkreasi. Dengan memanfaatkan anak muda, Kota Bandung saat ini mampu memadukan antara modernisasi dengan tradisi dan bersifat terbuka dan menerima keberagaman yang ada ${ }^{11}$.

h. Komunikasi. Komunikasi dilakukan sebagai upaya menyelaraskan semua pesan komunikasi yang bersifat intensional. Untuk mengembangkan potensi dan mebentuk branding Kota

\footnotetext{
${ }^{11}$ Dila Fatmala, 2012, Perancangan City Branding Kota Bandung, Skripsi Sarjana pada Fakultas Desain Universitas Komputer Indonesia Bandung: http://elib.unikom.ac.id/gdl.php?mod=browse\&op= read\&id=jbptunikompp-gdl-ditafatmal-2852
}

Pekanbaru tidak hanya sekedar membuat visi dan strategi, tetapi bagaimana strategi dan upaya tersebut dikomunikasikan dengan baik kepada seluruh stakeholder. Menarik kesimpulan dari penelitian terdahulu, peneliti menyimpulkan bahwa komunikasi tersebut menjadi dua bagian, yaitu komunikasi internal dan eksteranl. Komunikasi internal dilakukan antara atasan dengan bawahan (vertical), komunikasi antara rekan kerja dengan sesame karyawan (horizontal), pengadaan pelayanan informasi dan keluhan sebagai fasilitas untuk masyarakat, mengadakan acara budaya, pembuatan banner, poster, brosur, spanduk, logo, slogan dan perbaikan infrastruktur. Komunikasi eksternal, di sisi lain, dilakukan dengan media massa dan bekerja sama dengan kegiatan kepariwisataan.

Komunikasi tersebut juga dapat memanfaatkan media agar pesan yang ingin disampaikan jadi mudah dipahami oleh publik. Dengan memanfaatkan media, Pemerintah Kota Pekanbaru perlu membuat tagline visual serta pencarian gagasan visual. Pembuatan Tagline Visual, penilaiannya diambil dari apa yang selama ini melekat oleh Kota Pekanbaru, baik itu nilai positif maupun negatif. Ini meliputi pertanyaan bagaimana penilaian yang ada pada benak masyarakat juga 
menjadi poin penting dalam membentuk sebuah branding Kota Pekanbaru. Setelah menemukan brand yang tepat, kemudian dibuatlah sebuah tagline yang sesuai dengan brand yang telah dibuat sebelumnya. Brand tersebut didukung pula dengan pembuatan logo atau maskot yang berhubungan dengan branding Kota Pekanbaru.

Kemudian perlu dilakukan pengembangan tagline yang ingin disampaikan sehingga terbentuk beberapa gagasan visual yang nantinya akan dipilih dan tagline tersebut dapat mewakili potensi yang ada di Kota Pekanbaru. Sebagai contoh, Kota Pekanbaru dapat melihat proses rebranding Yogyakarta dalam membuat sebuah logo dan tagline. Mirip dengan Kota Pekanbaru, Kota Yogyakarta juga memiliki potensi kota dimana potensi tersebut dimanfaatkan untuk membuatsebuah ikon yang saat ini dapat kita jumpai pada logo dan tagline baru Yogyakarta. Ikon tersebut berupa pohon beringin kembar, tugu, andong, wayang, keraton, becak, merapi, pantai dan lampu antik. Sembilan ikon tersebut menjadi acuan pembentukan logo dan tagline, sehingga komunikasi mengenai branding sebuah kota juga ditunjukkan melalui sebuah logo.

Sebuah logo dan tagline tidak hanya berupa kata-kata mengenai sebuah kota, baiknya sebuah logo dantagline mewakili Kota Pekanbaru sebagai kota yang memiliki beragam aset budaya, seperti paduan warna yang mencerminkan keberagaman budaya tersebut. Serta mewakili Kota Pekanbaru sebagai pintu gerbang utama untuk menyambut wisatawan.Tagline tersebut nantinya dapat diletakkan di gapura, transit ads, umbul-umbul, dan ruang publik lainnya.

\section{PENUTUP}

Potensi wisata Kota Pekanbaru dalam penelitian ini dibagi menjadi empat sektor, yaitu potensi wisata seni budaya.Sektor seni budaya lahir dari etnis Melayu yang berasal dari Kesultanan Siak Sri Indrapura. Kemudian wisata kuliner berupa makanan khas Melayu seperti pancake durian, bolu kembojo dan asam pedas baung dimana makanan khas dan souvenir khas Kota Pekanbaru ini dapat ditemui di wisata belanja pasar bawah. Wisata alam yang ada di Pekanbaru, yaitu wisata Alam Mayang dan potensi yang tengah dikembangkan untuk menjadi ikon wisata sejarah yaitu di kawasan Sungai Siak, salah satunya yaitu adanya Water Front City (WFC), bus air dan cagar budaya rumah singgah Tuan Kadi. Tidak melupakan sejarah Kerajaan Siak Sri Indrapura, Kota Pekanbaru memiliki wisata sejarah yang beberapa peninggalannya diletakkan di Museum Sang Nila Utama dan Perpusatakaan 
Soeman HS, Mesjid Agung dan Mesjid Raya Senapelan. Wisata sejarah ini menjadi saksi bisu bagi perkembangan Kota Pekanbaru. Namun sayangnya, dari hasil penelitian, peneliti melihat bahwa Pemerintah Kota Pekanbaru sangat kurang dalam mengoptimalisasikan potensi yang ada, bahkan tidak ada upaya pembentukan strategi city branding. Padahal, letak kota yang strategi dan dikelilingi dengan kabupaten yang berpotensi dalam segi Sumber Daya Alam (SDA) dan Bandara Sultan Syarif Kasim II yang ada di Pekanbaru sebagai ibukota Provinsi Riau, dapat menjadi peluang besar bagi Kota Pekanbaru. Adapun Kota Pekanbaru memiliki potensi seni budaya, potensi kuliner, potensi alam, dan potensi sejarah.Melalui optimalisasi potensi dengan membentuk strategi yang efektif, Kota Pekanbaru dapat mendatangkan pemasukan daerah yang cukup besar.

Bukan hanya Pemerintah Kota Pekanbaru yang bertugas untuk mencapai branding kota tetapi seluruh stakeholder perlu turut serta mendukung pembentukan city branding Pekanbaru. Dalam upaya pembentukan branding tersebut, penulis merancang strategi komunikasi yang mengacu pada kerangka kerja branding kota oleh Kavartiz untuk mempromosikan Kota Pekanbaru melalui beberapa media pendukung. Pertama, mengkaji ulang mengenai visi dan strategi yang berhubungan dengan branding kota sebagai pintu gerbang budaya Melayu. Kedua, melakukan sinergi antar stakeholder agar terciptanya kerjasama yang baik, maka masing-masing pihak akan fokus melaksanakan tugasnya untuk mencapai branding Kota Pekanbaru. Ketiga, melibatkan warga lokal, pengusaha, dan pebisnis dalam mengembangkan dan mengantarkan brand. Keempat, sebagai pintu utama menyambut kedatangan wisatawan, tentunya, Kota Pekanbaru menjadi kota transit yang baiknya memanjakan mata wisatawan terhadap infranstruktur kota yang kental akan budaya Melayu. Kelima, perlunya pembentukan ruang publik yang mewakili branding Kota Pekanbaru sebagai pintu gerbang budaya Melayu seperti pembentukan taman terbuka untuk aktifitas kebudayaan. Keenam, segala aktifitas pembangunan tidak lepas dari budaya Melayu yang telah melekat pada Kota Pekanbaru. Ketujuh, melibatkan masyarakat Kota Pekanbaru khususnya anak muda yang saat ini memiliki gaya hidup urban. Kedelapan, komunikasi melalui sebuah tagline yang sesuai dengan brand yang telah dibuat sebelumnya.Brand tersebut didukung pula dengan pembuatan logo atau maskot yang berhubungan dengan branding Kota Pekanbaru.Tagline tersebut nantinya dapat diletakkan di gapura, transit ads, umbul-umbul, dan ruang publik lainnya. 


\section{DAFTAR PUSTAKA}

\section{Buku}

Satori, Djam'an dan Aan Komariah. (2012). Metodologi Penelitian Kualitatif. Bandung: Alfabeta.

Syahbana, Boy. et. al. (2014). Branding Tempat: Membangun Kota, Kabupaten, dan Provinsi Berbasis Identitas. Jakarta Selatan: Makna Informasi.

\section{Data Skripsi/Jurnal}

Primasari, Ina et.al. (2013). City Branding Solo Sebagai Kota Wisata Budaya Jawa (Studi Deskriptif Kualitatif tentang City branding Solo sebagai kota wisata budaya Jawa oleh Dinas Kebudayaan dan Pariwisata kota Solo). Skripsi Sarjana pada FISIP Universitas Sebelas Maret Surakarta: tidak diterbitkan.

Wijayanto, Ardy. (2014). Strategi Kegiatan Kehumasan Pemerintah Kota Dalam Membangun Identitas Kota Menjadi The New Singapore. Skripsi Sarjana pada FPSB UII: tidak diterbitkan.

\section{Internet}

Fatmala, Dila. (2012). Perancangan City Branding Kota Bandung. http://elib.unikom.ac.id/gdl.php? mod=browse\&op=read\&id=jbptun ikompp-gdl-ditafatmal-2852 diakses pada tanggal 3 Februari 2016 pukul 21.05.

Gonbe, Weirdbot. Metode Pengumpulan Data, http://www.academia.edu/8o249 55/ METODE_PENGUMPULAN_ DATA diakses pada tanggal 3 Mei 2015 pukul 13.29.

Vanolo, Alberto. (2007). The Image of The Creative City: Some Reflections on Urban Branding in Turin. Vol. 25 issue 6, December 2007. http://www.sciencedirect.com/scie nce/article/pii/So2642751080007 72. Diakses pada tanggal 9 Juni 2015 pukul 20.22. 